\title{
Bulgaria: transition revised - social fragmentation and the increase in poverty
}

\begin{abstract}
The transformations of the last twenty years in Bulgaria have split the social stratum into very many fragmented pieces, such as: low-cost labour; a low technological level; low investment and rates of return; lost markets; doomed pensioners; failed businesses; inadequate salaries; failed reforms in the public sector; and, perhaps most importantly, a fresh increase in the poverty level and social disequilibrium, added to the increased purchases of one-way tickets for an ever-increasing share of young labour migrants. The country is already in its fourth year of full membership of the EU, but it has many obstacles to overcome. Meanwhile, the economic situation in Bulgaria offers two paradoxes - an education market paradox (expensive state-funded education services, marketed as 'social goals'); and a labour market paradox (the pay rates of salaried workers are equal to or lower than the pay rates of waged workers). Thus, efficiency on the labour market, which should be a result of the quality of educated individuals, is both ambiguous and controversial.
\end{abstract}

Keywords: labour migration, demographic crisis, wage differentials, neoliberalism, social security, pensions reform, active employment policies, self-employment, unregistered employment, EU, influence of international financial institutions

\section{Introduction}

The two central problems of Bulgarian society, which directly affect the trade-off between efficiency and equity, are: first, the demographic crisis (which is accelerated by two other factors: low-cost labour migration; and the 'brain drain'); and, second, the economic and social transformation coupled with the issue of the levelling up both of the standard of living and of the incomes of individuals and households to an acceptable level. The demographic problem has been an issue for many years and, as will be clarified below, it has been unsuccessfully addressed by a series of governments not only during the period of transition, but even prior to that. Economic and social reforms, however, are new phenomena - their effects were tested for the first time in the period after the initiation of the crisis in 2008; and it is apparent that they have totally failed.

Bulgaria is a country situated in the very south-east corner of the EU-27, with a population of 7563710 people as of 1 January 2010. Currently, Bulgaria is suffering a severe demographic cataclysm, as a result of twenty years of a negative natural growth rate. For example, the birth rate in 2009 was $10.7 \%$ while the death rate was $14.2 \%$.

The demographic picture over a comparatively long time-frame - i.e. from the beginning of the twentieth century up to now - is even more catastrophic. For instance, in 1900 there were 130000 marriages and 240000 births, while in 2009, marriages 
numbered only 25923 and just 80956 births. Marriage and divorce statistics show that the marriage coefficient dropped from $4.4 \%$ in 2004 to $3.68 \%$ in 2009 , while the divorce coefficient dropped from $1.61 \%$ to $1.56 \%$ for the same years.

It is also worrying that more than $53 \%$ of new-born Bulgarian children were born out of wedlock. This demonstrates that public perceptions of the values of marriage have changed. In addition to the population statistics, the average age of men going into a first marriage is 29.6 years and 26.4 years for women; while the average marriage duration decreased to fourteen consecutive years.

Therefore, the Bulgarian nation is slowly declining and the population is aging at faster rates compared with other European Union states. Moreover, the labour potential of the population is diminishing. Bearing in mind the negative demographic growth and the decline in the marriage rate, it is worth mentioning that the average life expectancy of a Bulgarian man is 69 years while in the EU-27 this figure is 70.4 years; for women, the average is 76 years compared to 78.7 years in the EU-27.

Demographic distortions in Bulgarian society have also led to significant structural problems for the labour market. Both the diminution in social mobility and the increase in income inequalities, coupled with social tensions between the different age generations, have become a central issue for public finances as well as for mechanisms for the distribution and re-distribution of public wealth and the tax burden.

Another dimension to consider in analysing what has really changed in Bulgarian society is the economy. The country is still in a process of transition from a commandadministrative economy to a market-driven one, and it should be pointed out that the leading sector of the economy is now the services sector, which creates jobs for more than $70 \%$ of the labour force. However, this was not the case just a couple of decades ago. For example, in the 1950 s the agricultural sector contributed $31.3 \%$ of the GDP of the country, the industrial sector $40.6 \%$ and the services sector $28.1 \%$. ${ }^{1}$

The 'Industrial Leap' of the country occurred in the 1960s and 1970s, when about two-thirds of the GDP of Bulgaria was the result of mass industrial production.

Hence, job opportunities which were related to industrial and agricultural production, such as tractor drivers, farmers, miners, builders et cetera, were promoted during the time of 'state socialism' far more than jobs which were related to services, education and science. The present pyramidal structure of occupational incomes which are financed through the state budget remains essentially the way it used to be. Wage differentials between the highest and lowest in the public sector, as well as between the highest and lowest pensions in payment, are not particularly significant. In addition to the lack of adequate wage differentials, the minimum wage and the minimum level of pensions lag behind the inflation rate and do not even successfully meet poverty criteria.

For 2011, legislators set the minimum pension at BGN $136(€ 68)$ per month and the maximum pension at BGN $700(€ 350)$. The present level of the so-called 'poverty line' in the country (as of 2010; it is set to be the same for 2011) is BGN 211 per month $(€ 105)$. Another important indicator for the national economy is the minimum wage, which is still defined by a command-administrative mechanism (the Council of Min-

1 National Statistical Yearbooks of Bulgaria (Statisticheski godihnitsi na Balgaria) - selected years. 
isters issues a Decision on the minimum monthly pay rate), and which is set at BGN 240 ( $€ 120)$ for 2010 (and 2011). A recent discussion in the European Parliament (October 2010), stating that the lowest possible minimum wage in a given country should be set at $60 \%$ of the average wage rate for that country, triggered much tension and disputes in Bulgaria. Such a move would set the minimum wage in Bulgaria at about BGN 360 per month ( $€ 180$ ), which is considered to be a 'very high' wage by Bulgarian employers and the ruling government.

In addition, since 1997 - that is, since the introduction of the Currency Board - a policy of the periodic 'freezing' of wages in the public sector, social allowances, pensions and other payments financed through the state budget has been consistently followed. The argument which is presented to the general public to justify such policies is that the incremental indexation of public expenditures will destroy both the financial and budgetary stability of the country. These neo-liberal innovative policies seem to be the main reason why Bulgaria occupies the very last position in the EU ranking in terms of the levels of poverty and income disequilibrium.

Another reason for the employment of such neo-liberal policies is that, over the years, all governments have intentionally maintained wage rates at a low level, believing that such a policy would create true competitive advantage which would strategically allow Bulgaria to perform better economically when compared with other central and east European countries. These particular specifics of the socio-economic transition explain why the trade-off between efficiency and equity in the Bulgarian case may not be interpreted through the prism of the dominant concepts and criteria which the academic literature instructs us to follow. Even in practical guides for building 'prosperous societies' and 'welfare states' in a united Europe, the policies do not serve these needs. ${ }^{2}$

The imported neo-liberal model in Bulgaria is not of the EU type. This is why the restrictions of the budgeting model, and that of fiscal and monetary management in implementation, do not include the idea of a trade-off in its construction. Instead, this trade-off is replaced with pre-set standardised criteria for the evaluation of efficiency. Standardised bonus points for the efficiency of economic and social policies are rated by level of dependence on the macro parameters of the country. For example, the lower the inflation rate, the higher the bonus points for efficiency; while the lower the state expenditure, the greater the bonus points; and so on. Thus, this simplified framework for efficiency evaluation has altered the very essence of the trade-off debate in Bulgaria.

The very first thing which needs to be done is to conduct nationwide field research and then to build comparative analyses and answer different questions. One of the central questions to be researched is whether market fundamentalism has been fruitful in strategic planning, in terms of bringing the country greater competitive advantage in a globalised world; or whether it has been to the contrary - i.e. whether the social gap between developed EU states and Bulgaria has been preserved, widened or diminished. And the very three dimensions of the trade-off - incomes, employment and education - seem to have a rather negative interpretation in the Bulgarian case. 
The focal point of the analysis is founded on a comparison between two time periods:

a) the pre-accession period (from the mid 1990s to 1 January 2007, when Bulgaria became a fully-fledged member of the EU)

b) post-accession - which, in fact, covers the very beginning of the economic crisis up to now.

\section{The case for a trade-off in social policy}

Strong social and egalitarian perceptions and policies used to prevail in Bulgaria; currently, however, that is no longer the case. Political considerations rather than economic and social criteria have given a new impetus to the way social policies are elaborated and adopted in the public and private sectors of the country.

It has to be pointed out that there is a 'National Council on Tripartite Co-operation', which is meant to serve not only as a consulting body but also as a decision-making one. During the last couple of years, however, this body for national social partnership has been blamed by statesmen and analysts apparently attempting to construct a second centre of executive power.

Consequently, 'the social partners' who participate in this Council (representatives of the state, representatives of nationally-recognised trade union organisations and representatives of nationally-recognised organisations of employers) should bear significant responsibilities for setting social targets and policies. Nevertheless, it is understood that the social and pension reforms at the dawn of the political changes in the early 1990s have already failed. In addition, the national economy and the social sphere are mismatched now the country is situated in a new locus - Bulgaria ought to abide by the stricter EU regulations and policies recommended by the international financial institutions (IFIs), which have incurred a substantial monetary and fiscal burden for the population of the country.

The other institutional factor which may seem, at first, to have had an indirect impact on the country refers to the IFIs. In recent years, however, the IFIs happen to have had a more direct impact than was expected. In Bulgaria, as is the case with almost all states from south-east Europe, the IMF and the World Bank have imposed multi-annual projects aimed at social engineering and the transformation of national economies and social systems driven by market mechanisms. It is reasonable, however, to look at whether the market mechanisms which have been imposed in south-east Europe are the same as those adopted in developed EU states. And the only correct answer is that, in the south-east Europe region, a very specific design of economic mechanisms has been adopted which may be considered as an ultra-neoliberal model which does not exist in developed EU states. ${ }^{3}$

Simply said, it is not the European social model that has been applied in south-east Europe but the Anglo-Saxon one. And it is this Anglo-Saxon model (which has been tested in very many third-world countries and which has not produced the expected results) that has been presented as a benchmark of reform for all post-socialist states. 
In Bulgaria, there is a network of lobbyists which happen to provide active and, in given cases, aggressive support to the neo-liberal orthodoxy. This support includes the involvement of:

a) 'institutes' for market analyses and strategies, designed particularly and financed by foreign funds originating from Anglo-Saxon territories

b) think-tank centres supported both by Bulgarian and foreign businesses

c) opinion leaders and media which take up market fundamentalist positions.

It must be recognised that all those who have implemented neo-liberal concepts on Bulgarian soil have succeeded in their efforts. It is another issue, however, to detect and name the losers in such neo-liberal experiments. These losers happen to be the middle class, the working poor and the remaining low-income groups in Bulgaria.

The 'economic success' of Bulgaria, measured by the neo-liberal criteria for effectiveness, may be seen in all dimensions of social policy:

1. low wages result in greater competitiveness

2. low corporate taxes result in much freer capital for enterprises

3. low social security charges result in more disposable income for individuals.

Regrettably, what had been expected was not achieved because:

1. competitiveness did not improve but wages have remained inadequately low

2. free capital was not re-invested but consumed in very many 'prestigious' ways

3. the low social security charges happen to be among the lowest of all EU states and, virtually, have ruined the social security system.

There is a great deal of cost accrual in the ways that the social and pension reforms have been conducted as a result of the requirements, which Bulgaria must meet, in terms of introducing modern social facilities, modern social services, new technologies in the service sectors, new working modes, and so on.

Recently, there has been a great deal of discussion on when a re-start of the reforms would be announced; and it seems that this re-start has been delayed, in practice, until 2012, as the suggested new laws are expected to be adopted during 2011. In any case, changes in both the Labour Code and the Social Security Code must be initiated and implemented.

A modernised social security system requires a modernised Labour Code, and this seems to be one of the factors that frustrate many Bulgarians. Essentially, change in social security results from the change in the labour laws.

Traditionally, Bulgarian workers are classified in three categories, according to different factors (complexity of job duties; work under stress; work in dangerous conditions; etc.). Workers in the third labour category prevail, as this is the category of labour duties which least affects an individual's life in a negative way. The envisaged changes in the social security sector have been initiated as regards this third category of workers, since the new law will stipulate that the working period for legal retirement is to be increased by four months each year. Thus, the total accrual of working years for an individual to reach the legal age of retirement and, therefore, to be entitled to a pension become 37 years for women and 40 for men; this target is set for 2020 .

The budget of the country for 2011 is estimated at a GDP equal to BGN 77bn ( $€ 33.5 \mathrm{bn}$ ), but the 2009 budget failed and the 2010 budget was revised twice; hence, 
the popular belief is that this figure is quite unreachable given that the country is in a state of severe crisis. In addition to the official forecast, there are some other estimates for the social sector. It is estimated that, in 2011, there will be only 2815005 individuals who will pay social security taxes and be considered as 'socially secured'. And, statistically, security charges are estimated to be applied to an average monthly income of BGN 610 (€ 305).

The minimum income level, at which a citizen must pay his/her social security charges, is set at BGN 240 ( $€ 120)$, which is the minimum monthly pay rate for labour. However, it must be underlined that the minimum gross wage of BGN 240 is subject to social security deductions and income taxes and, therefore, the minimum net wage comes to about BGN 189 ( $€ 95$ ); that is, below the poverty line of $€ 105$ set by the government. Moreover, in very many outlying places of residence, as well as in small villages and towns close to the borders of the country, there have been registered cases of four-hour working shifts per day which, in practice, means that the net income of some individuals is halved, from $€ 95$ to $€ 48$ per month

Currently, discussions are focused on what type of pension plans and schemes should be applied, including whether a pension should be the result of both the length of the working period of an individual and the size of the contribution to the social security system of the country, which is a very controversial idea in Bulgarian society. In Bulgaria during the years of socialism, there was no special social security fund established. Even today, the idea of having a specialised fund, which is deemed to pay higher pensions to those who have contributed more, is not a principle which is very much liked by the general public. In practice, to pay the pensions of this population of $2.2 \mathrm{~m}$ retired people, state officials must impose higher social security charges on individuals who are currently working, as the monetary contributions of the older generation had never been deposited and managed in a single social fund.

This is why state officials are seriously discussing another condition before someone may become entitled to a pension - i.e. the increase in the legal age for retirement. This age is planned to be increased to 63 years for women and, for men, to 65 . The targets are set at 2026 for women and 2024 for men. Thus, the monetary size of an individual's pension would depend on three primary factors:

1. the period of working during which social contributions are made

2. the monetary size of the social contribution

3. the age of the individual.

The situation in the social security sector is actually worse since, no matter that the planned reforms may start as early as 2012 , there will still be a large budgetary deficit in the National Fund for Pensions until at least 2016. Presently, this deficit is estimated at BGN 2bn ( $€ 1$ bn). In 2017, the balance sheet of this National Fund is estimated to equalise the inflows and outflows for executing pension plans with no continuing deficit. Basically, therefore, 2017 is considered to be the milestone year for the pensions system of the country, on the presumption that today's estimates are likely to be correct.

The country has adopted two main documents for social protection: (1) the National Report on the Strategies for Social Protection and Social Inclusion of the Republic of 
Bulgaria - 2006-2008; ${ }^{4}$ and (2) the National Report on Strategies for Social Protection and Social Inclusion 2008-2010.5 However, it is the finances of the state which will not allow these strategies to be executed properly.

For example, as a result of budget restrictions and limited funds for social protection, low-income families happen to be the ones which are most affected. A low-income family in Bulgaria is considered to be a family which has an income of less than BGN 350 ( $€ 175)$ per person per month. In order to provide social assistance to these people, in a situation of reduced budgets and limited funds, the statistics for December 2008 show that there were 572963 families whose income classified them as socially disadvantaged. For this reason, the state distributed to 844522 children from these poor families a monthly allowance of BGN 35 ( $€$ 17.50) per month per child. In December 2009 , the number of disadvantaged families grew to 584635 and the number of children who were entitled to the monthly $€ 17.50$ allowance increased to 851006 . $^{6}$

Virtually, the social security sector in Bulgaria is, at present, administratively regulated (on a top-down basis), while the principles of command-administrative decisionmaking and decision-imposition are still preserved. Personal or community involvement in the processes of planning, providing and controlling social security processes have been totally eliminated and the modes of the so-called 'central-planning' way of doing things have been revitalised.

Official estimates for 2011 demonstrate that the social services sector (which is commanded primarily by the Council of Ministers) will be entitled to BGN $8.2 \mathrm{bn}$ (€4.1bn), which equates to about $5.3 \%$ of the GDP of the country. A significant percentage of this amount - about $85 \%$ - will be paid out in pensions alone. The remaining $15 \%$ will be distributed at the discretion of the government on an as-needed and ongoing basis.

The National Fund for Pensions of the country (which is still referred to under the strange name of 'State Community Social Security Provision') is estimated to be likely to accumulate BGN 5.56bn ( $€ 2.78$ bn) in 2011, but must pay out BGN 6.7bn ( $€ 3.35$ ) in this very same year. Therefore, there will be some deficit of around BGN $1.2 \mathrm{bn}$ ( $€ 0.6 \mathrm{bn}$ ). And, in respect of this deficit, it is as yet unclear how it will be settled - by subsidy from the national budget of the country; by a credit line from foreign institutions; by credit from the banking sector; by the issue of state bonds and securities; or in some other way.

In practice, the social services sector in Bulgaria is primarily related to accumulating, managing and paying out the cash flow responsibilities of the currently applied pension scheme. All other aspects of the social policies of the government have been postponed to the 'bright future'. This would include policies to combat poverty; policies to de-institutionalise places for public care (to change the command-administrative

4 National Report on Strategies for Social Protection and Social Inclusion of the Republic of Bulgaria - 2006-2008 (in English) http://www.mlsp.government.bg/en/docs/National_Report_SPSI_Final_EN.doc.

5 National Report on Strategies for Social Protection and Social Inclusion 2008-2010 http:// www.mlsp.government.bg/en/docs/EN\%20NSR\%202008-2010.rar.

6 Agency for Social Support Annual Statistics http://www.asp.government.bg. 
mechanisms for private management mechanisms); policies to 'humanise' public care for people with disabilities (such as introducing special telephones, special institutions, special vehicles and other things which might ease the way of life of socially-deprived people); policies aimed at helping single-parent families; and other socially-oriented policies.

It was stated earlier that changes in the Bulgarian tax code, initiated immediately after the country joined the EU and at the dawning of the economic crisis, were aimed at:

1. radical improvements in the competitive potential of the nation

2. increased new inflows of foreign investment

3. the creation of incentives for national capital to turn into productive investment

4. the creation of new jobs.

At first glance, a single tax rate of $10 \%$ on corporate profits and the incomes of individuals (cancelling the minimum non-levied income level) had to serve as a fiscal guarantee that all the stated aims would be achieved. However, the actual data for 2007-2010 indicates a mismatch against the estimates. For instance, for 2009 and 2010, foreign direct investment (FDI) decreased a couple of times: some analysts expect FDI to have dropped from about $€ 3$ bn in 2008 to about $€ 1$ bn at the end of 2010 . Both Bulgarian and foreign businesses have limited (to the lowest possible minimum) their investment in new production capacities and have retained the use of credit, sending capital abroad.

It was the middle class and low-income individuals who were, in the main, burdened by tax collections in 2008, 2009 and 2010, according to the fiscal statistics. Meanwhile, income inequalities worsened as a result of the introduction of flat-tax rates.

The political class and the so-called 'new rich' will certainly defend all that was conquered in the transition period, building a new social and economic agenda for the country. Under their agenda, tax privileges are for the rich, priority access to EU funds is for big companies and only a limited re-distribution of national income towards poorer social strata is envisaged.

In summary, modification of the social pyramid in Bulgaria has already been accomplished. However, this was neither completed in accordance with the values and principles of the social market economy, nor has it been focused on European traditions of social solidarity. Social policies in the country remain rudimentary and they happen to have become a sub-domain of 'strategically important', and endless, market-oriented reforms. Ultimately, reforms in the health-care system, social security system, education system and other cornerstone systems which normalise social justice in the country seem to have greater complementary importance in government strategies instead of being first priority for officials of the state.

\section{The case for a trade-off in employment policy}

Employment policies were among the top governmental priorities before 1989 . Being a command-administrative system, the country utilised numerous 'institutional measures' to create jobs and to 'place' workers the way that the then ruling party considered to be the right one. Currently, these command-administrative mechanisms no 
longer exist, as in a market economy 'employment-at-will' should prevail and individuals should sign labour contracts guided primarily by free will and their own interests.

In the days before the big political change in 1989, virtually all workers were members of, or else were affiliated to, the ruling party trade union. The country had about four million workers (in 1988), all being members of the trade union. In addition to that, the 'working class' was considered to be of a 'proletarian kind' which brought all progress to the country. Political propaganda, being synchronised with Soviet labour propaganda, considered hard workers to be the most productive part of Bulgarian society. In those days, a university graduate in education, for example, could start a professional career as a teacher in mathematics and was 'entitled' to receive a monthly wage of BGN 120 to 150, whereas a miner could easily start on more than BGN 300 .

Unlike the present day, where unemployment is considered to be a natural phenomenon of the market economy, unemployment did not exist in socialist Bulgaria; in contrast, there were employment surpluses and hidden unemployment. Being at a very low technological level, the country easily created many job openings related to general labour as well as positions which did not require much skills or education. For positions which required formal education or specialist skills and knowledge, it was the principle of 'appointment' that was utilised, not the principle of 'free competition'. And, in practice, at a time when no private enterprise existed and when private entrepreneurship was criminalised, it was the local party leader who decided whether an individual was not only capable of doing a job but who would also be loyal to the ruling party, so that a proper decision would be taken, with decision-making being part of the duties of the job.

Another distortion of natural labour relations was the general view that social equality could be achieved only by equal incomes. This is why the system did not differentiate between hard workers and 'lazy' ones - all received equal pay. And having no monetary incentives for better performance in the workplace, labour malpractices started to prevail. Having virtually no wage differentials in the national state-funded and state-administered economy, Bulgarian society did not have many opportunities to benefit from the intellectual capacity of the nation. Job occupations in the service sector and primary professions which required specialised skills and knowledge, such as surgeons, lawyers, financial analysts, aviators, et cetera, were greatly under-valued (bearing in mind that private practice did not exist at that time).

Taking into consideration that wages for industrial job occupations and jobs in the agricultural sector were significantly greater than pay rates for jobs in the service sector, one may easily comprehend why the country is now the least developed state in the EU-27. And, in addition to the legacy of socialism, during the last twenty years of political and economic transformation it is a "market economy without a middle class' ${ }^{7}$ that has been established in Bulgaria.

Analysing the dynamics of employment after 1989, one may easily detect three periods. The first period relates to industrial and sectoral re-structuring - from 1990 to 2001. During this period, the privatisation of most large Bulgarian enterprises was 
completed, while the privatisation of enterprises on a smaller scale was also conducted. The private sector reached nearly $70 \%$ of the GDP of the country. The social result of this unprecedented transformation was the loss of more than one million jobs and mass unemployment of over $20 \%$ on an annual basis.

The second period encompassed the interval from 2001 to 2007, when Bulgaria demonstrated stable and continuing economic growth, due primarily to the greater speed of development in certain sectors, particularly in the construction sector, real estate and trade and merchandised services. In this period occurred a re-structuring of the labour market - some sectors of the economy experienced a diminishing of labour demand while new jobs were created in other sectors. The Bulgarian labour market became more segmented than before; and regional segmentation, sectoral segmentation and the segmentation of physical and intellectual labour was induced. Segmentation on the labour market created much unemployment, but this unemployment was primarily reduced in this second period by the higher rate of migrants leaving the country.

In 2007, annual unemployment was near $6 \%$, and some politicians and analysts took this as a sign of forthcoming stabilisation and prosperity.

The third period is one of the global economic crisis, which entered the Bulgarian economic space with a lag of six to ten months, depending on the region in the country and the sector of the economy. The unemployment rate started to increase slowly, but steadily, and currently (in October 2010), it is over $9 \%$ which means that, statistically, the country has about 340000 registered unemployed.

The EU initiated its so-called 'Luxembourg Process' and set in place the framework for the European Employment Strategy (EES) in 1997, ${ }^{8}$ but there is not much evidence that Bulgaria has gained full advantage from following the already-established EU principles of managing the processes in the labour market.

The very first attempts to modernise which occurred on the labour market in Bulgaria were made in 2003, when the government approved the so-called 'National Action Plan for Employment' (NAPE). Subsequent to that year, the Council of Ministers of Bulgaria has approved new measures and policies to stimulate employment through government subsidies. In 2007, these government subsidies were budgeted at BGN $190 \mathrm{~m}(€ 95 \mathrm{~m})$; in 2008, they were budgeted at BGN 197m (€ 100m); while in 2009 the subsidy was again set at $€ 100 \mathrm{~m}$.

Recent labour market statistics for the first half of 2009 show that the number of individuals employed in the industry sector is 1177900 (or about $36 \%$ of all those employed), while the number of employed people in the services sector is 1873100 individuals (or about $57 \%$ of all those employed). The remaining $7 \%$ of employees (230 000 individuals) occupy jobs in the agricultural sector.

The employment policy philosophy in NAPE-2010 is to combat the negative consequences of the economic crisis as regards the labour market. Employment policy is targeted at the secondary labour market, for which the state provides monthly subsidies for the creation of jobs. For each unemployed individual who gains a job through the secondary labour market, the monthly payment is set at BGN $240(€ 120)$, i.e. at the minimum monthly wage level.

8 Employment Summit http://ec.europa.eu/employment_social/elm/summit/en/. 
NAPE-2010 also stimulates the employment of young college and university graduates through a special programme called 'Start a Career'; the state subsidy for such an individual is budgeted at BGN $400(€ 200)$ per month. There are some other programmes to stimulate employment, such as the 'Support Maternity Programme', under which an individual would gain a subsidy of BGN $350(€ 175)$ per month if they are employed. There are also subsidies for individuals with disabilities to re-integrate in the labour market which are set at BGN 350 (€ 175).

Under NAPE-2010, the state has budgeted additional subsidies for the education of the unemployed, with the state subsidy per unemployed person being set at BGN 600 $(€ 300)$ per month. For purposes of the education of employed people, the state subsidy is set at BGN $300(€ 150)$ per month.

Summaries have already been released of the outcomes of The National Reform Programme of Bulgaria 2007-2009, ${ }^{9}$ the Report for Year- $2007^{10}$ and the Commission's Assessment. ${ }^{11}$ The reports of the other members of the EU-27 have also been published ${ }^{12}$ and comparisons between the position of labour in Bulgaria and in the rest of the EU may be conducted.

Considering recent data for the labour market in Bulgaria during the first quarter of $2010(\mathrm{Q} 1 / 2010),{ }^{13}$ the statistics show a number of trends.

Individuals not included in the workforce number $1.74 \mathrm{~m}$ (from the 15-64 age group) while individuals from the same age group who compose the workforce of the country number $3.31 \mathrm{~m}$. Official statistics count children aged between 15 and 18 as 'capable of working', but this is not the case in Bulgaria, since the General Inspectorate of Labour must obtain the permission of parents/guardians and then authorise the labour contracts of minors at specified preferential working conditions. It is general practice, however, for such minors to work illegally, or not to work at all, even though national statistics considers them 'capable of working'.

Another important issue on the labour market is that the workforce of the state is composed both of the employed, numbering $2.97 \mathrm{~m}$, as well as the unemployed, numbering 339,000. Of all those who are employed, national statistics comprehends the category of 'employers' as having 'working status'; this category constitutes about $4 \%$ of total employment. There are, additionally, $1 \%$ to $2 \%$ 'non-paid family workers' in total employment; there is another statistical difference here between Bulgaria and Eurostat since the latter considers this category of workers as 'family workers' while Bulgarian statistics comprehends them as 'non-paid family workers'. A third category

9 Summary of the National Reform Programme of Bulgaria 2007-2009 http://www.aeaf.minfin.bg/en/documents/NRP/summary_en.pdf.

10 Progress Report on the National Reform Programme 2007-2009 http://www.aeaf.minfin.bg/ en/documents/NRP/progress_report_en_2007.pdf.

11 Commission's Assessment of the National Reform Programme 2007-2009 http://ec.europa.eu/ growthandjobs/pdf/european-dimension-200712-annual-progress-report/200712-annualprogress-report-BG_en.pdf.

12 Implementation Reports of EU-27 on their National Reform Programmes related to the Labour Market http://ec.europa.eu/growthandjobs/national-dimension/member-states-autumn-2007-reports/index_en.htm.

13 National Statistics Institute of Bulgaria www.nsi.bg/EPDOCS/RabSila2010q1.pdf. 
of workers, according to 'working status', is the self-employed, which consists of some $7 \%$ to $8 \%$ of the total number of employed people. Hence, the largest group, according to working status, is the group of 'employed workers' (the concept of 'working class' is still widely used in the country), which varies between $85 \%$ and $88 \%$, although, statistically, the total number of 'employed workers' in Q1 of 2010 approximated to no more than $2.6 \mathrm{~m}$ individuals.

Of all 'employed workers' in the Bulgarian economy in 2009, the greatest share of employed individuals $(24.6 \%)$ are those who are involved in the processing industry; the second largest share is those who are employed in retail trade $(16 \%)$; while the third largest $(9.8 \%)$ is made up of those who are employed in the construction sector. The subsequent leading sectors of the economy, all with similar percentages of employment, include: education sector $(6.9 \%)$; transportation and logistics $(6 \%)$; state governance $(5.2 \%)$; medical and social services $(5.1 \%)$; and hotels and restaurants $(4 \%)$.

Sectors of the national economy which involve large amounts of intellectual capital - such as the IT, financial and real estate sectors - have the following respective share of employment: $2.4 \% ; 2.2 \%$; and $1 \%$.

Nowadays, some two-thirds of the GDP of the country is due to the services sector, but the economy is at a very low technological level and it is still believed that market competitiveness is primarily due to the low cost of labour. This is why the economy of Bulgaria is more labour intensive, coupled with a comparatively low level of productivity. Manufactured goods are not competitive at all, while the services provided are of a very low quality and are unreasonably priced.

Besides the structural problems of the economy, there is another more significant one. The labours of the average Bulgarian worker may be described as constituted of a 'not very well thought of type of work; tasks that are poorly-started; no decisionmaking rationale; a job half-done'. ${ }^{14}$

Another intrinsic problem on the labour market is the perception of the owners of capital and their 'appointed' managers that the only human resource management style is that of 'the carrot and the stick' - but without the carrot. Numerous are those managers who believe that only an authoritarian style of management will help them achieve set goals. However, an even greater percentage of present managers does not have the necessary management skills and knowledge to motivate employees to work more productively. And research studies suggest that Bulgarian employees are among the most unmotivated workers in the world. ${ }^{15}$

The EU is aiming at the introduction of fair labour standards and practices (in a series of EU directives and reports), but this framework of fairness in labour relations meets the strong opposition of many Bulgarians. Put simply, the parties involved in a contractual relationship for labour do not share similar values. Monetary relations now prevail in the Bulgarian economy, so most employers and workers compute their wellbeing on the basis of costs and incomes. And most employers, believing that reducing 
labour costs will give them competitive advantage in the market, have reduced the pay rates of workers to almost the survival minimum.

Estimates exist, from one of the Bulgarian trade unions, that about 400000 workers receive a minimum gross wage of $€ 120$ (net $€ 45$ ); and that the average gross pay rate in the economy is $€ 300$ (net $€ 230$ ), while the standard cost of living is estimated at $€ 250$ per month.

The central problem as regards the employment policies of all governments is that they have introduced and followed too liberal a course of action, bearing in mind economic rationality and leaving aside real social dialogue and the balance of interests. Even though certain legal steps have been initiated to modernise and adapt employment policies in the country (such as introducing the Law for Employment Promotion (LEP) ${ }^{16}$ in 2002, for example), there is little evidence that actual state policies on the labour market are helping people to find better and well-paid jobs.

Considering the economic and financial crisis, which has lowered the standard of living of most Bulgarians, more and more workers are considering labour migration within the EU as the primary work-and-life option to level up their standard of living and their well-being, as well as to satisfy their needs and consumption preferences.

Certainly, Bulgaria offers some other options to its labour force, such as self-employment or employment in the shadow (unregistered) economy.

The self-employed initially composed $3-4 \%$ of the labour force of the country, but the share of this group now constitutes some $8 \%$. Bearing in mind that the total labour force of Bulgaria is, for the first quarter of 2010, about 3 million, the number of selfemployed individuals is, thus, around 240000 people. This figure is highly significant by Bulgarian standards since it is very similar to that of discouraged workers, which currently totals 227000 individuals (among the 15-64 age group, Q1/2010).

From the moment of the accession of Bulgaria to the EU, the number of individuals who had left their job occupations as workers, and tried subsequently to establish their own micro-businesses, has increased; now, these individuals compose a very significant segment of the Bulgarian labour market. It is challenging to establish a successful business in Bulgaria, but many people have, indeed, demonstrated, a real spirit of entrepreneurship. This is expected to increase in the near future if the present trends of the expansion of this labour segment are preserved.

Unregistered employment was, initially, viewed by ordinary workers as an economic crime but rates of unregistered employment, although statistically undetected, happen to have increased over time. This phenomenon can be explained by the series of economic 'shocks' which the country has had to survive. Following the first 'shock wave' of the privatisation of Bulgarian enterprises, succeeded by the deliberate restructuring of the sectors of Bulgarian industry, the average worker has started to reconsider attitudes towards taking a job in the informal sector. The informal sector, and informal employment itself, have become a safe economic zone for irresponsible entrepreneurship, labour malpractice, tax evasion and other economic and financial misdeeds: this was certainly a zone where free capital was available to all involved.

16 Law on the Promotion of Employment, 2002 (in English) http://www.benl.org/doc_en.php? DID=307, information checked on 1 April 2009. 
Some analysts believe that unregistered employed comprises $30-35 \%$ of the labour force of the country, although the phenomenon is not statistically recorded. The country has, however, initiated some administrative and legislative measures to put barriers in the way of this process.

Recent research conducted by the Bulgarian Industrial Capital Association (BICA $)^{17}$ in 2010 demonstrated that $48 \%$ of business leaders and $52 \%$ of individuals interviewed firmly believe that the share of the shadow economy in Bulgaria is significantly large - larger than $38 \%$.

\section{The case for a trade-off in education}

For any modern state, education plays a central role in the economic growth of the country and in terms of the well-being of its citizens. Recent research, in 2007 and 2008 , shows that the share of employees in the private sector in Bulgaria who have a degree from an institute of higher education is $25-27 \%$ of all those employed in the private sector; while individuals employed in the public sector who have a higher education degree compose some $75-80 \%$ of all those employed in the public sector. ${ }^{18}$

The services sector accumulates $72 \%$ of all employees in the country at present (Q1/2010) and this sector is also demonstrating very dynamic growth. The distribution of employees by educational degree varies from year to year but, in any case, employed individuals who have completed college or university (tertiary education) compose around $25 \%$ of all employees. Individuals who have no more than a high school diploma (secondary education) consist of about $60 \%$ of all employees in Bulgaria and the remaining percentage (about $15 \%$ ) refers to individuals who have only primary or no education. Therefore, the national economy is endowed with much low-skilled and low-qualified labour. Labour-intensive processes are related to the really low costs of production - about BGN 1.5 to 2 ( $€ 0.80$ to $€ 1)$ per working hour. Most employers follow the classical rule of wage formation, under which the wage should equal the marginal product of labour, and so low salary and wage levels prevail in the national economy.

The result of the low costs of labour and the low wage levels is that, hence, there is less intensive private consumption. Low wages do not induce consumption processes which are sufficiently intensive to stimulate businesses to produce more, and a vicious circle is thereby created: low wages - low consumption; low consumption - low production; low production - low market; low market - low sales; low sales - low wages; and so the circle starts again. And, consequently, the percentage of unemployed individuals who have a higher education degree varies between $5 \%$ and $8 \%$ of all the unemployed; unemployed people with a completed secondary education compose about $50 \%$ of all the unemployed; and the remaining percentage relates to individuals who have lower or no education.

17 The Bulgarian Association of Industrial Capital (BICA) http://www.bica-bg.org.

18 Collected Works 2010, in Bulgarian: 'Konkurentni pozicii na universitetite i vishite uchilishta na pazara na truda v Balgaria' ('Competitive Positions of the Universities and Schools of Higher Education on the Labour Market in Bulgaria'), publishing house of the University of Plovdiv, p. 20. 
In the early 90s there were no private education institutions, whereas for the 2009/10 academic year, the country has 43 universities, 42 colleges and 23 specialised schools of higher education. Therefore, there are at present 108 institutions which provide, in one way or another, higher education services to the general public. This growth of education institutions is paralleled by an intensive process of college enrolment. For example, for the 2000/01 academic year, the net enrolment coefficient of the population in the 19-23 age group was $26 \%$ while, in 2009/10, this figure, for the same age group, is $41.1 \%{ }^{19}$

Currently, the number of all enrolled students in Bulgarian colleges and universities for the 2009/10 academic year totals 287086 , and around $95 \%$ of all these enrolled students are of Bulgarian origin. Bulgaria has 3850 students who are enrolled in $\mathrm{PhD}$ programmes as of January 2010.

In 2009, according to statistical data, Bulgaria had 69302 high school graduates and 57803 college and/or university graduates.

The growth of education institutions and student enrolment, particularly in the tertiary system of education in the country, is due primarily to the education services provided by institutes of higher education happening to provide greater monetary benefits for all graduates, unlike previously.

Employers recruiting a labour force from the labour market now value the acquired educational knowledge, skills and experience of individuals to a greater extent. Thus, wage differentiation has started to appear as a natural phenomenon of the Bulgarian labour market, although these wage differentials are not yet very significant.

For example, the average gross monthly wage in March 2010 in the national economy was BGN 636 (€ 318), ${ }^{20}$ while for Q1/2010, it was BGN 619 (€ 309). Using these figures as benchmarks for the national economy, it is easy to see from the national statistics that the average gross salary for Q1/2010 for the Transportation and Storage sector was BGN 679 ( $€$ 340). Employers from this sector traditionally employ individuals with secondary, not tertiary, education. In Medical and Social Services, the average gross monthly salary was BGN 672 (€ 336). The very same low salary level relates to Education Services, where the average gross monthly salary was BGN 647 (€ 323). In the Extraction Industry, which demands more low-skilled and low-qualified labour than Real Estate, for example, the gross average monthly salary was BGN 987 (€ 494), while the average salary for workers in Real Estate was BGN 708 (€ 354).

It is obvious that, in many cases in the national economy, low-skilled labour is priced as high as, or even higher than, high-skilled labour. The idea of socialism that all people should be equal, which was taken to mean that all people should have equal incomes, is still alive in Bulgarian society. The very low technological level of industries found in the Bulgarian economy creates more jobs for low-skilled and low-educated individuals. Thus, highly-educated individuals, and individuals who have specific knowledge and skills, happen to be in less demand on the labour market and, in very many cases, they accept job positions which do not correspond to their high professional status.

19 National Statistics Institute of Bulgaria www.nsi.bg.

20 National Statistics Institute of Bulgaria http://www.nsi.bg/EPDOCS/EmplsSalary10q1.pdf. 
There are not very many jobs created for highly-educated individuals, so many such people seek job opportunities outside the national labour market, particularly in EU countries. Bulgaria is considered a full member state of the Union, but there remain strong barriers to high-skilled work migration within the EU for educated Bulgarians.

Strangely, the EU seems to have set a double standard in its treatment of work migration originating from countries such as Bulgaria and other less-developed countries of the EU. It has indeed liberalised that segment of the labour market which demands low-skilled workers, such as builders, pizza delivery people, messengers - or, in slang, it has liberalised competition for 'McJobs'. Some states of the Union, however, have not fully liberalised those segments of their labour markets which require intellectual capital. And surely, individuals of Bulgarian origin, who have greater levels of intellectual capital, would ask for higher pay rates when searching for jobs in a developed EU state.

At times, when the European Parliament has been discussing the introduction of a 'blue card' for intellectuals from China, India, Brazil and other countries, it is not taking account of the very citizens of this Union (Bulgarians, in this particular case), who pay taxes and who thus finance the EU Treasury but who gain no advantage on the EU labour market. Furthermore, the country is still excluded from the Schengen territories of the EU and operates outside monetary union.

However, despite certain barriers on the EU labour market for educated and highskilled Bulgarians, there is much evidence that Bulgaria faces a severe 'brain drain'. Simply said, educated Bulgarians are leaving their jobs in the national economy with an average monthly salary of $€ 300$ and searching for whatever job positions they may find in developed EU states. And this is, surely, a process of the indirect financing by poor Bulgaria of the richer states of the EU.

An issue to be considered in particular is the very sharp increase in educated migrants leaving Bulgaria and heading for the more developed EU states and the US, as well as some new labour destinations such as Canada, Australia, New Zealand or southeast Asia. And, in recent years, these migration patterns have shifted significantly: to those who were looking for permanent job opportunities abroad, the category of young individuals and students may be added. For example, Bulgarian students are the second largest group in Germany after the Chinese.

Some analysts are already alarmed at the systematic attempts of the developed states of the EU to attract individuals who have acquired intellectual capacity and skills in their countries of origin, via the provision of fee-waivers for study, monthly allowances or even free-of-charge higher education (such as in some Scandinavian states).

The result of these distortions in the labour market as regards the national economy is that not only is the economic growth of the country endangered, but so is the intellectual endowment of Bulgaria.

The problem for Bulgaria in terms of education is that, initially, a unilateral reform of the education system was started, administered by three Bulgarian governments in turn, with the active assistance of the World Bank. The unilateral character of the reform was that it sought to change the profile and the number of education institutions in accordance with selected fiscal and monetary criteria. Thus, some savings in the na- 
tional budget were reached in various years, although this was at the expense, however, of the limited budget for education institutions in the country.

Ultimately, an outcome has been reached: in 2011, for the first time in its modern development, Bulgaria is about to spend only $3.3 \%$ of its GDP on education and science. This figure is two to three times lower than the spending of the rest of the member states of the EU. In setting monetary and financial goals for the education sector, mainly through massive cost-cutting, access to education services has been strongly reduced and the quality of education severely affected. Due to the austere administrative and financial restrictions, the school drop-out rate has now officially reached $15 \%$ and, for the Roma minority, this figure is above $50 \% .^{21}$

Sluggish labour market integration between the developed and developing states of the EU emits controversial signals as regards the general public and the ordinary citizen. There is no doubt that Bulgarian citizens do correlate their EU citizenship with higher wage levels and standards of living, but this correlation seems to be rather more mediafuelled than real.

\section{Conclusions}

In conclusion, it could be stated that the trade-off between efficiency and equity in Bulgaria may have only one strategically and politically correct solution. This solution must fundamentally alter the wrongly-set model which has been imposed by the socioeconomic transition. The new model should adopt pro-EU approaches, supported by EU decisions in the spheres of social politics, employment and education. More specifically, the country needs accordingly to establish new conditions by which the European social model and the EU's set of values must be adopted. In this radical way, Bulgaria's priorities will become the setting of an EU-style of decision-making and resource allocation as the norm for political and business behaviour.

In order for such a change to happen, the following combination of events should occur:

1. Bulgaria must disassemble the neo-liberal model which defines, presently, its policies in the education and employment sectors, and in terms of incomes. This neoliberal model must be altered through transfers and the infusion of such type of decision-making processes and procedures which have passed the test of time in developed EU states. For example, the dogma for low wages as a pre-condition for the establishment of a competitive economy must be totally abolished. The idea has to be introduced that, in order to have sustainable growth in the economy, a country should have higher productivity rates and a higher quality of labour, and that this must be adequately financed. This type of employment policy may be initiated by the state and a national consensus on the setting of higher pay rates needs to be achieved. Business and opinion leaders should be much more involved in popularising the idea of decent incomes and a decent life for working individuals. Work should not be a mode of survival, as is the reality for numerous workers at present, but should have a value as well as being a way legally to achieve a decent standard of living. And, most importantly, greater social and labour demands

21 Nikolay Tilkidzhiev (2010) Otpadashtite Romi Publishing House Iztok/Zapad. 
should be set year-after-year such that Bulgarians could attain the standard of living enjoyed by individuals in other EU states.

2. The EU must revise the strategy and criteria which it applies to value social effectiveness and social equality in Bulgaria and in other EU member states. It has been proven that national governments should not be left alone, particularly in times of crisis. The EU should not allow national governments to be misled by models which produce short-term or questionable effects, or models which have never been tested elsewhere. Said straightforwardly, social policy cannot be proclaimed as the domain of national sovereignty when drastic differences exist between the member states of the EU. In cases of obvious failures in the economic and financial performance of a state (the Greek case, for instance), or in cases of the availability of a plethora of evidence that social regression is inducing crime, corruption, bribery, usury, etc, the EU must have a direct hands-on approach.

3. The big issue for Bulgaria, as well as for most states from south-east Europe, is that these countries have provided full access for the international financial institutions to their national databases and other such critical information so that these institutions may suggest economic and social reforms. For example, the IMF and the World Bank have returned to Bulgaria, having once left the country, after a period of over fifteen years of supervision. Their return is again coupled with the very same austerity measures and programmes, and decisions, full of conditionalities, similar to those imposed during the pre-crisis period. To prevent the proliferation of this phenomenon, it is high time that the EU started to play a more pivotal role through the setting of the economic, political and social agenda in the less-developed member states of the Union. 